\title{
Christian-Moslem Relations after the Second Vatican Council Luboš Kropáček
}

\section{Introduction}

Commemorating the half-century that has elapsed since the Second Vatican Council incites us in new conditions with new energy to reflection and discussions on the manner and extent to which the Council's intention of aggiornamento - opening the Church up to the contemporary world has been fulfilled. The discussions so far, both intra-Church and broadly extended general ones, on the significance of the Council as a major landmark in church history have recorded both positive reviews and variously pointed out scepticism. When the $40^{\text {th }}$ anniversary was commemorated, Benedict XVI, at that time in the early phase of his pontificate, in a Christmas 2005 exhortation, said that in discourse of the Council it is inadequate to speak in terms of a hermeneutic of "break and discontinuity" and advocated the conception of "hermeneutic of reform", in which continuity and discontinuity can be perceived in mutual interplay. ${ }^{1}$ Of course, their extent differs at various levels. We can certainly accept this view and elaborate on it in the topic dealt with in this paper. An evident change was without doubt brought about by the documents adopted in the conclusion of the Council's last year, i.e., especially the pastoral constitution Gaudium et spes (ratified on December $7^{\text {th }}, 1965$ ) and several weeks before it the Declaration on the Relation of the Church to Non-Christian Religions Nostra aetate (ratified on October $28^{\text {th }}$ ). This declaration, its efficacy and the challenge it continues to pose in the evermore interconnected, culturally and religiously pluralist world is that our focus here.

\section{The Council's message}

We are quite well informed of the motives and procedure of the Council's reform thoughts concerning the relationship to other religions from the rich documentation. The starting point was brought by John XXIII's decision to cleanse Church doctrine and the liturgy of Good Friday of anti-Jewish elements that may have in the past nourished anti-Semitic tendencies with their horrific culmination in the Holocaust. In this field it was really a matter of reform parting with tradition and a new evaluation of the relationship to the Jews. Since the Council the Church perceives

1 Cf. BENEDICT XVI, Weihnachtsansprache, in: Das Zweite Vatikanische Konzil. Die Hermeneutik der Reform, Kurt Kardinal KOCH, Augsburg: St. Ulrich, 2012, pp. 9-19. 
them with respect as "people of the Old Testament" or "older brothers in faith". ${ }^{2}$ The Council confirmed that the origin and inspiration of the two parts of the Bible belong together, i.e., the unity of the two Testaments, by the dogmatic constitution Dei verbum (the constitution was adopted on November $18^{\text {th }}$; their co-belonging is mentioned in article 16). Recently, Pope Francis in his apostolic exhortation Evangelii Gaudium exhorted us in the same spirit to friendly dialogue with the people of the Old Testament. ${ }^{3}$

At the Council, in the international situation of constant Israeli-Arab tension, the initiative to adopt a decree friendly only to the Jews first met with serious problems. The proposal was withdrawn under Arab pressure; it was obvious that it would have negative repercussions in the situation of Christians in the Near East. After dramatic negotiations efforts to extend the topic to a more extensive perspective of the Church's relationship to non-Christian religions crystalized. Such a more general conception certainly was in good accord with the Council's striving for an open relationship to the contemporary world, as it was in its final form expressed by Gaudium et spes. Making a statement on Islam, besides Judaism, also gained significance - political and theological.

The part played by Pope Paul VI may without doubt not be overlooked. He was well informed on the third monotheistic religion already at the time when as Archbishop of Milan he cultivated friendly relations with the orientalist, pioneer of Christian-Moslem relations Louis Massignon. Already in the first year of his pontificate, in January 1964, Paul VI visited the Holy Land and in that way started a new tradition of papal foreign travels. In Bethlehem he addressed, besides the Christians there, the Moslems and Jews in a friendly manner as those who believe in the one, true, living God, the God of Abraham. However, this conception of adoring the only, i.e., the same, God whom the Moslems adhere to as we do is not unambiguously accepted whether in the different Christian churches or by all Catholic theologians. There are even reservations to labelling the three monotheisms "Abrahamic religions". ${ }^{4}$ In Paul VI's words: "(together) with us they worship God" (nobiscum Deum adorant). He used them in the encyclical Ecclesiam suam and it was employed in the Council constitution Lumen gentium in the chapter on God's people (article 16) and later also in the Catechism of the Catholic Church (no. 841).

Already in the first sentence of the first of the two paragraphs devoted to Islam the declaration expressed a fundamental attitude: the Church regards Moslems with respect. The text further explains this attitude by agreement or significant closeness in Christian and Moslem doctrine and manner of piety and urges a departure from the past dissensions and effort at mutual understanding and cooperation for positive goals. It ought to be underlined that the friendly biddings speak of Moslems; it is therefore a matter of good relations with people of different faith, who share the created world with us, and let us say that today - half a century after the Council - they represent 1.6 billion of our contemporaries. The declaration nowhere mentions the Koran, nor the prophetic mission of Mohammed, i.e., theological topics where the parties in dialogue can only acknowledge the difference of opinion. The Council avoided deeper theological probes or constructions - as it did in the cases of other non-Christian religion. For example, ideas of a special

2 Detailed analysis of the Council's proceedings on Judaism and their further implications is offered by the paper: Jan-Heiner TÜCK, Das Konzil und die Juden, Religionen unterwegs 3/2015, pp. 9-15.

3 Cf. FRANCIS, Evangelii gaudium, 248 and following. Further, only EG and section number.

4 Cf. Rémi BRAGUE, O Bohu u křestanů a o jednom nebo dvou dalších, Brno: CDK, 2011. 
Ishmaelic line of the history of salvation elaborated by Abbé Michel Hayek, ${ }^{5}$ a Lebanese professor at the Institut Catholique in Paris were not regarded. But in a footnote the declaration mentions a letter from Pope Gregory VII (of 1077) to the Algerian prince Al-Nasir acknowledging that we confess one God, though in different ways. ${ }^{6}$

This single reference - from a time whose spiritual climate two decades later was dramatically marked by the first crusade - softens only slightly the more strongly perceived view that the Council brought an absolute break in the Church's relationship to Moslems. It is sometimes labelled a Copernican turn. Of course, the history of Christian-Moslem dialogue knows other friendly efforts - from Francis of Assisi through Nicholas of Cusa's De pace fidei to the missionary opinion of the 19th century that in the Asian and African milieu Islamic monotheism can prepare the ground for evangelization. Nonetheless, Nostra aetate brought an altogether new approach corresponding to the needs of an altogether new period. Its turbulences have put efforts at dialogue to serious tests, whose further variations and results remain open.

\section{Christian initiatives}

Efforts to put the Council spirit in to practice began already while it was still in progress. Already by 1964 the Secretariat for Non-Christians was founded in the Roman Curia, later (in 1988) renamed to Pontifical Council for Interreligious Dialogue. Its section for Islam published Orientations for dialogue between Christians and Moslems (Rome, 1969), with later updated and elaborated versions published in numerous translations to European and Eastern languages. ${ }^{7}$ The Pontifical Institute for Arabic and Islamic Studies (PISAI) was transferred to Rome. The institute was originally founded in Tunisia in 1926 by the "White Fathers", a congregation focusing on missionary activities in Africa; now in Rome it could, also due to the personal care of Paul VI, develop a rich scholarly and educational activity devoted to Christian-Moslem relations in general. Of the outstanding personalities of PISAI and the developed dialogue let us mention at least the author of the Orientations Maurice Borrmans. In a similar spirit the World Council of Churches (based in Geneva) actively focused on dialogue with the extensive initiative called Dialogue with People of Living Faiths. In the original version of 1970s "faiths" were mentioned along with "ideologies", since dialogue was also aimed at people subjected to Marxist indoctrination.

Practical knowledge and, especially, experience with the fast growing presence of Moslem minorities in European countries have shown the real need for ecumenical collaboration of the Christians of all churches and denominations. It proved beneficial in the shared initiatives of the Roman Catholic Council of European Bishops' Conferences (CCEE) and the Conference of European Churches (KEK) grouping together Orthodox, Protestant, Anglican, Old Catholic and independent churches. Charta Oecumenica, signed at Easter $2001,{ }^{8}$ became an important document for their cooperation in Europe. In the $11^{\text {th }}$ chapter it speaks of the effort to sustain Christian-Is-

5 Cf. Luboš KROPÁČEK, Rané křestanství a vznik islámu, Teologické texty 4/1999, pp. 110-113. The paper lists the bibliography of Hayek's monographs on Ishmael's, i.e., Arab, parallel path to the Old Testament history of salvational effort and expectation.

6 Cf. Dokumenty II. vatikánského koncilu, Praha: Zvon, 1999. Declaration Nostra aetate 3.

7 E.g. Maurice BORRMANS, Orientations pour un dialogue entre chrétiens et musulmans, Paris: Cerf, 1981 and other editions.

8 Charta Oecumenica. Guidelines for the Growing Cooperation among the Churches in Europe. For KEK it was signed by Metropolitan Jéremie and for CCEE by Cardinal Miloslav Vlk in Strasbourg on April 22 ${ }^{\text {nd }}$, 2001. Subsequently it was published in all European languages, including Czech. 
lamic dialogue, to speak together of faith in the one God and of human rights. The cooperation of CCEE and KEK had already at that time a good experience with the activity of the shared, equally composed Committee for "Islam in Europe". While it was active in 1987-2003 it worked out a number of study documents and recommendations to help churches understand and cultivate attitudes to the new Moslem neighbours, as well as proper pastoral work in the culturally pluralist Europe. ${ }^{9}$

The dialogue gradually developed in a number of forms, from local initiative forms of conversations and cooperation to establishing contacts at high representative level, represented on the Christian part by the Holy See or the World Council of Churches and on the Moslem part, e.g. by the al-Azhar in Cairo or the Iranian Shiite Qom. Important documentary and investigative centres were established at national church level (such as CIBEDO in Frankfurt or CADR in Milan), as well as at international and interreligious level (Groupe de Recherches Islamo-Chrétien). All meetings and steps taken towards a better mutual understanding and relations have since 1975 been carefully monitored by the revue Islamochristiana, published by the Roman PISAI. Naturally, the attitudes and travels of John Paul II were widely acclaimed, especially his speech to the youth of Morocco at a stadium in Casablanca (August 19 ${ }^{\text {th }}, 1985$ ) and the peace prayer meeting of many religions in Assisi (in 1986). The Pope repeated them with an even greater emphasis in January 2002 following the Forum of Religious Representatives in the Vatican, convoked with the goal of alleviating the escalated manifestations of enmity between the West and the Moslem world after the terrorist attacks of September 2001. ${ }^{10}$ In general it is possible to say that Christian initiatives found partners on the Moslem part among some of the spiritual leaders, in some institutions and especially among liberal intellectuals. Already in the 1970s some initiatives came from the Moslem party, especially in Tunisia and Amman, where good intercultural relationships have for years been supported by Prince Hassan bin Talal. ${ }^{11}$ An interesting hotspot of good will from a number of sides arose on historic ground in Andalusian Córdoba. ${ }^{12}$ Unfortunately, good efforts on both Christian and Moslem part collide with the radicalization of anti-West extremism in Moslem countries, nourishing a similar radicalization of islamophobia and the growth of anti-Moslem moods and parties in Europe.

\section{Radicalization in Moslem milieu}

In the 1960s, to which the friendly spiritual climate the Second Vatican Council belonged, trends of cultural convergence with the West were prevalent in the Moslem world. Nationalist ideas were dominant, especially Arab nationalism, and also forms of socialism or mixed economies and steps towards democracy. An orientation break was brought by painful defeats of Arab countries in the Six-Day War with Israel (1967) and of Pakistan in the war with India, associated with the separation of Bangladesh (1971). The bitter view that in fatal crises the foreign, especially Western and generally post-Christian world will always take the enemy's part became widespread; it is therefore necessary to

9 Some of the findings of this Committee were published in Czech in the paper Luboš KROPÁČEK, Křestané tváŕí v tvář islámu v současné Evopě, Teologické texty 5/1999, pp. 158-161.

10 The Papal Council for Interreligious Dialogue published the conclusions of the assembly in Assisi in the collection Peace: A Single Goal and a Shared Intention: Forum of Religious Representatives (Vatican City, January 23 ${ }^{\text {rd }}, 2002$ ), Day of Prayer for Peace (Assisi, January $24^{\text {th }}$, 2002), Vatican City: Pontifical Council for Interreligious Dialogue, 2002.

11 Prince Hasan, incidentally a frequent participant in Havel's conferences of Fórum 2000 in Prague, published a dispassionately and irenically conceived overview of Christian churches in the Arab Near East: El Hassan Bin TALAL: Christianity in the Arab World, Royal Institute for Inter-Faith Studies: Amman/London, 1995. A Czech translation is to be published in 2016.

12 In 1974, 1977, 1986 and 1987 Córdoba became the stage for colloquia. Developing an intercultural centre in Córdoba was for some time pursued by Roger Garaudy, who after a period of searching in the field of Marxism and Christianity converted to the Islam (1982) and discredited himself by relativizing the Holocaust; he died in 2012. 
reject all foreign ideologies and rely exclusively on their own values, embodied by the Islam. Thought of this kind was ripening throughout the 1970s and captivated worldwide attention by the events of 1979: the triumph of the Islamic revolution in the Iran, occupation of the Great Mosque in Mecca by armed rebels on the day when the $15^{\text {th }}$ century began according to the Islamic lunar calendar, and at the end of the year in December the Soviet invasion of Afghanistan, which instantly scattered a great part of the positions and illusions that the Soviet luring of Moslem countries had attained.

In the following decade the idea of global jihad against occupation by adherents of other faiths was born in Afghanistan, transferred further to other conflicts among Moslem populations and foreign political interests. Vicarious impacts of the Cold War brought Lebanon to civil war for 15 years (1975-1990); the country, which seemed to offer excellent terrain for Christian-Moslem dialogue, was on the contrary disrupted under false confessional labels by agents of bipolar division of the world and the as yet unsolved Israeli-Palestinian conflict. New types of division crystalized soon after the end of the Cold War (1989/90) into new theoretical paradigms, in which the position of threat was occupied by radical Islam, replacing the collapsed communism. Francis Fukuyama, enthusiastically celebrating the worldwide triumph of liberal democracy, ${ }^{13}$ labelled only China and the Moslem world as enclaves of difference; he called the Moslem world an "empire of resentment", bitter because it had not been able to keep its traditional values, nor successfully master new ones for world competition. A few years later Samuel Huntington introduced his influential schema of the pluralist world of civilizations, established around their religious cores, and the potentiality of their clash. ${ }^{14}$ In that he paid great attention to the Islamic civilization, which he conceived as an ancient rival and threat for the West. In fact he was warning of inter-civilization conflict, but the stunt-hungry media greedily grasped all news of conflicts in the Moslem world and its boundaries and presented them as fulfilment of a premonition. The terrorist attacks of September $11^{\text {th }}, 2001$ seemed to confirm the prognoses of evil.

\section{Present situation}

For already approximately a whole generation the polarization in Moslem societies has been progressing and continues to intensify even today. To its general background belongs without doubt the continuing - though in recent years moderated population growth and together with it also the increase in wealth - possibilities and activity of oil monarchies, especially of Saudi Arabia with its strict, puritan and at the same time strongly assertive conception of Islam. The tendency to require strict regulation of life according to the exemplar of "reverend ancestors" (as-salaf as-sálíh) from the $7^{\text {th }}$ century, i.e., by currents of salafíah, put strong pressure on the faithful who wish to have more freedom for life in the world of the 21st century. Polarization pressures and counter-pressures intensify to violent conflicts, in which impacts of international events are reflected and continue to have effect. Radicalization has been supported by tendencies to global jihad during the latent war in Algeria and after the breakup of Yugoslavia in Bosnia; tested precedents are then followed by wars with greater possibilities and efficiency in other broken-up countries: Somalia, Iraq, Syria, Lebanon, Yemen and elsewhere. Radical Islamist currents in northern Nigeria, at present represented mainly by the terrorist group Boko Haram, also present a major danger. The so-called Islamic State, territorially anchored in the north of Iraq and Syria (ISIS, 
Da ish) also gives great space to global jihadism. In all cases the radicals in their rhetoric as well as terrifyingly brutal practices are inimical to Christians. In this respect they cross the limits that had been set by the "reverend ancestors" (salaf). Christians in Moslem countries - mostly designated by the Quran expression nasárá ("of Nazareth") - are at present subject to persecution at a historically unprecedented measure.

No Moslem state has acknowledged the brutal formation of ISIS. Through membership in the UN and by accepting its Charter these states have de facto laid aside the medieval Islamic view of the world and accepted the secular plurality of its international structures. But remnants of an asymmetry in the state-religion relationship remain. Saudi Arabia still refuses to legalize Christian worship in its territory, while Western states headed by the USA do not try to get their partner to behave reciprocally in the field of religious freedom. The political conditions are not favourable to Christian-Moslem dialogue. Nonetheless, there are some hopeful signs to note. In the first place they are the solidary appearances of not small numbers of average Moslems expressing support to Christian co-citizens exposed to the barbarian behaviour of the extremists. Recently we have seen such manifestations towards the Egyptian Copts; they appear - besides their brute opposites - also in Syria and Iraq.

Initiatives of Moslem spiritual authorities addressing Christian churches with open messages are also worth attention. The Common Word of Ramadan 2007 was widely acclaimed. The document was signed by 138 outstanding Moslem personages of different countries; according to some it was to cover up the irritated reactions that had a year before followed after an unfriendly reception of Benedict XVI's lecture at the University in Regensburg. The document starts from the Quran verse "People of the Book! Come now to a word common between us and you..." (3:64) and exhorts the Christians and Jews to common thought and action in the spirit of serving the one God. It abundantly employs the term "love", characteristic of Christian approaches, while in Islam (apart from Sufism) it is used much less frequently. In the following year (2008) the Saudi king Abdallah visited the Pope in the Vatican, spoke of peace among Moslems, Christians and Jews and called for dialogue. As its principles he highlighted the rejection of racism, acknowledging differences among humans that God had apparently wished for, and the need to face shared challenges in a world blemished by materialism, disintegration of the family and the decline of moral values.

The crisis of the Islamic world has deepened conspicuously in recent years. There has long been talk of war in the heart of Islam, ${ }^{15}$ today it has grown from opinion clashes to bloodshed. Disputes over who represents the true or authentic Islam have become strongly polarized and multi-sided. The intentional world Moslem community (umma) lacks an acknowledged unifying authority; its place is occupied by the Quran, interpreted in very different or even contradictory ways, and the extensive tradition is disunited (differences between sunna - shiia) and in places not very trustworthy. The clashing parties mutually excommunicate each other (takfír). Important spiritual representatives of Moslem countries have attempted to define who is a Moslem in 2004-5 following the initiative of the king of Jordan Abdullah II; this is known as the Amman Message (Risálat Ammán). The friendly and broadly tolerant wording of the agreed document irritated the fundamentalists on militantly used social networks to denounce "Ammanism" or "Ammanists".

15 Cf. Gilles KEPEL, Válka v srdci islámu, Praha: Karolinum, 2006. The French original of 2004 bears a title beginning with the word Fitna - a term denoting schism in Islamic historiography; the first had occurred between the Sunni and the Shiite. 
They say they are the product of the 72 sects which, according to the well-known hadith, will be thrown to eternal fire. Such a curse is at present pronounced on the web of CIFIA (Correct Islamic Faith International Association, in short sahih iman), allegedly gathering 330 orthodox Islamic institutions based in the Indian Hajderabad. Any tolerant attitudes are taken to a political and war level by the ISIS, al-Kaida and related jihadist organizations.

Attacks on Moslem personages and currents denounced for "heterodoxy" include absolute rejection of dialogue with non-Moslems. In this respect CIFIA condemns the Jordanian royal initiative Amman Interfaith Message of 2005, in which Christians and Jews are designated as faithful and in that way placed side by side with Moslems. In Jordan the possibility to view Buddhists as faithful is allegedly considered. We can see here that the radical spikes of contemporary Islamic polarization condemn both a friendly interpretation of the Quran and the practice of the bright periods of Islamic history. On the contrary, possibilities of agreement and cooperation close to the notions of our Council documents are rising at the opposite pole.

Face to face with the schisms in Islamic societies it is necessary to see the whole complex situation, and study and discern it carefully. Dialogue is not possible with the militant pole of present Islamism, but with the moderate currents it is very much needed. Important topics are freedom of religion and respect for life. In that Christians receive the task of protecting and deepening the values with which they have been able to imbue the best aspects of contemporary modern civilization in the fast-reeling history of the Western world and the broader world affected by it. Protection means opposition both against Islamist fanatics and against those in Europe who, for their own power ambitions, play up to them in stirring hatred, affirming extremist interpretations of the Quran and not infrequently waving slogans of European values, which they deform to suit their ends. It is sufficient to recall the words of Pope Francis ${ }^{16}$ that authentic Islam does not side with violence and the open letter with which the Dutch critic of Islam Geert Wilders snubbed him for them. ${ }^{17}$ Austrian politicians try to support the positive interpretations with which liberal Moslems and their theologically-educated spiritual representatives defend the humane face of their religion; they see a way in the high-quality study of Islamic spiritual leaders at the University of Vienna..$^{18}$

To conclude, the following remains to be said: The present greatly unsettled wave of immigrants coming from Moslem countries to Europe gives rise to a significant increase of the local inhabitants' contact with Moslems. Already today this fact is a test of Christian genuineness, which will without doubt continue in further shared life. Accepting foreigners and a hand stretched out to help the needy can invigorate our own faith in dialogue with life, as well as our knowledge and appreciation of this faith on the part of those who are coming.

16 EG 252-253.

17 Cf. Geert WILDERS, Open letter of December 6 ${ }^{\text {th }}, 2013$ (on-line), at http://geertwilders.nl/index.php/in-english-mainmenu-98/inthe-press-mainmenu-101/77-in-the-press/in-the-press/1840-open-letter-to-his-holiness-pope-francis-by-geert-wilders, retrieved October $15^{\text {th }}, 2015$.

18 See Bundesgesetz über die äusseren Rechtsverhältnisse islamischer Religionsgesellschaften - Islamgesetz 2015, $\$ 24$, Theologische Studien. 


\title{
Christian-Moslem Relations after the Second Vatican Council
}

\begin{abstract}
The proposed paper reflects on the relations among the three great world religions confessing one God - Judaism, Christianity, and Islam - and their development since Vatican Council II up to the present. It notes that the Council denoted an important turn in the Catholic Church's attitude to the other two religions and exhorted Christians to view them positively. This message is contained especially in the pastoral constitution Gaudium et spes and the declaration Nostra aetate. The paper shows how the legacy of these documents is or is not realized in subsequent practice. It informs of initiatives supporting good relationships in various ways, ensuing from Christians as well as from Moslems. It points out that in the contemporary world, in which the mingling of cultures is increasing, interreligious dialogue is becoming more important and it is necessary to keep striving for it.
\end{abstract}

Keywords: Second Vatican Council, constitution Gaudium et spes, declaration Nostra aetate, Judaism, Christianity, Islam, interreligious relations

\section{Contact}

\section{Prof. Dr. Luboš Kropáček}

Charles University in Prague

Faculty of Philosophy, Department of Near Eastern and African Studies

Celetná 20, 11642 Praha 1

lubos.kropacek@ff.cuni.cz 